\title{
Role of sulfuric acid in chemical weathering of carbonate rocks for evaluating of carbon sinks in the Yangtze River Basin, China
}

\author{
Liankai Zhang1,*, Xiaoqun Qin ${ }^{1}$, Qibo Huang ${ }^{1}$, and Pengyu Liu ${ }^{1}$ \\ ${ }^{1}$ Institute of Karst Geology, Chinese Academy of Geological Sciences, Guilin, 541004 China
}

\begin{abstract}
Chemical weathering of rock by river systems is an important process in the global carbon cycle. Sulfuric acid produced from anthropogenic sources in the Yangtze River basin of China has the potential to change rock weathering processes and the carbon cycle. Monitoring and analysis of the dissolved constituents of the main channel and major tributaries of the Yangtze River indicate that the sulfuric acid has enhanced the carbonate rock weathering rate by an average of $28 \%$ and reduced the $\mathrm{CO}_{2}$ consumption rate by $12 \%$. Analysis of dissolved sources for $\mathrm{SO}_{4}{ }^{2-}$ in the Yangtze River indicates that $36 \%$ of $\mathrm{SO}_{4}{ }^{2-}$ can be attributed to rainwater, $26 \%$ to dissolution of evaporitic rocks, and $38 \%$ to input from coal. Calculations indicate that the annual output flux of $\mathrm{CO}_{2}$ from the Yangtze River Basin to the sea is $3495 \times 10^{4}$ tons, $80 \%$ of which is attributed to the weathering of carbonate rocks. Whilst the average consumption rate of atmospheric $\mathrm{CO}_{2}$ is $20.6 \mathrm{t} / \mathrm{km}^{2} \mathrm{y}^{-1}$.
\end{abstract}

\section{Introduction}

The Yangtze River of China is the third largest river in the world and its $\mathrm{CO}_{2}$ consumption through rock weathering plays an important role in the global carbon cycle [1, 2]. Previous estimates of carbon sink fluxes were based on rock weathering processes with the dissolution of carbonic acid [3]. Recent studies have shown that sulfuric acid formed by the oxidation of other low valence sulfur are also involved in the geochemical cycle of carbon and, therefore, also affect the carbon cycle in the river basin [4]. In this study, river water from the main stream and the major tributaries of the Yangtze River was sampled in 2013 for hydrochemical composition. Analytical results were utilized to determine the role of sulfuric acid in the weathering of carbonate rocks in the Yangtze River basin. Additionally, the consumption of atmospheric $\mathrm{CO}_{2}$ in the river basin was also estimated.

\section{Overview of the Yangtze River Basin}

The Yangtze River has a total length of $6300 \mathrm{~km}$ and its river basin covers an area of

${ }^{*}$ Corresponding author: zhangliankai@karst.ac.cn 
$1.8 \times 10^{6} \mathrm{~km}^{2}$ [5]. It has an annual average runoff of $900 \times 10^{9} \mathrm{~m}^{3} / \mathrm{y}$ [3] and branches off to 53 major tributaries. Topographically, the river basin has a multi-level terraced terrain that descends from an altitude of $5400 \mathrm{~m}$ at the west to the sea level at east. Geologically, Yangtze River Basin is located in the Yangtze shield, which is overlain with carbonate rocks, evaporites, and terrestrial clastic sedimentary rocks spanning the Precambrian era to the Quaternary period. Carbonate rocks are widespread in the river basin; it covers an area of $43 \times 10^{4} \mathrm{~km}^{2}$ accounting for $24 \%$ of the entire river basin area (Figure. 1). In which, the carbonate rocks are mainly distributed in the middle reaches of the Yangtze River. The annual average temperature increases from west to east in the range of -4 to $19{ }^{\circ} \mathrm{C}$. The annual mean precipitation of the river basin is $1067 \mathrm{~mm}$.

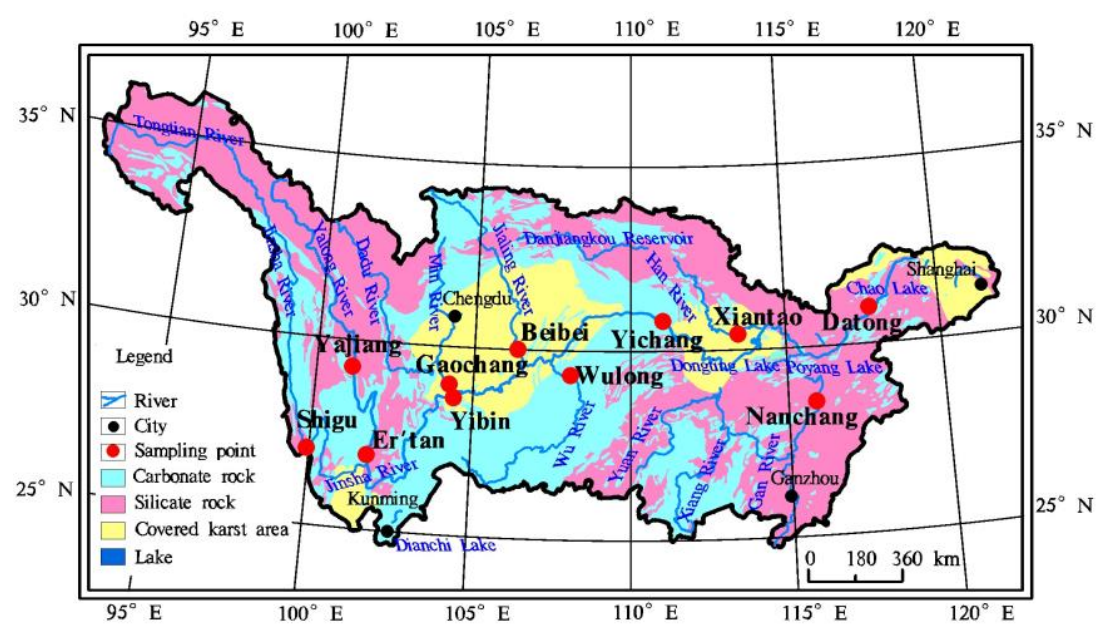

Fig. 1. Geological map of the Yangtze River basin and the sampling locations.

\section{Methodology}

We conducted a quarterly sampling and hydrochemical analysis of the main stream and major tributary streams of the Yangtze River basin in 2013. A portable multi-parameter meter (WTW, Multi 3420) was used at the field sites to make in situ measurements of water temperature, $\mathrm{pH}$ value, conductivity, and total dissolved solid (TDS). Samples were analyzed at the Chinese Karst Geological Resources Environmental Monitoring and Testing Center. Water chemistry was analyzed by a full spectrum direct reading spectrometer (IRIS Intrepid II XSP). From the literature, the isotopic composition of sulfur (relative to the CDT standard) for the Yangtze River basin is $\delta^{34} S_{\text {evaporite }}=25 \%, \delta^{34} S_{\text {river water }}=13 \%$, and $\delta^{34} S_{\text {rain }}$ $=-2 \%$ [2]. In this study, we used the daily hydrological data for 2013 from the Chinese National Water and Rain Information Network.

\section{Results and discussion}

\subsection{Hydrochemical evidence for the role of sulfuric acid in rock weathering}

The relationship between chemical equivalent concentrations of $\left[\mathrm{Ca}^{2+}+\mathrm{Mg}^{2+}\right]$ and $\left[\mathrm{HCO}_{3}{ }^{-}+\mathrm{SO}_{4}{ }^{2-}\right]$ in the main stream and tributaries of the Yangtze River Basin is illustrated in Figure 2. The $\left[\mathrm{Ca}^{2+}+\mathrm{Mg}^{2+}\right] /\left[\mathrm{HCO}_{3}{ }^{-}+\mathrm{SO}_{4}{ }^{2-}\right]$ ratios of all samples ranged between 0.90 and 
1.29 , with an average value of 0.99 , which indicates that the $\mathrm{Ca}^{2+}$ and $\mathrm{Mg}^{2+}$ ions in the river are balanced by the sum of $\mathrm{HCO}_{3}{ }^{-}$and $\mathrm{SO}_{4}{ }^{2-}$. This ionic balance indicates that both carbonic acid and sulfuric acid are involved in the chemical dissolution of carbonate rocks.

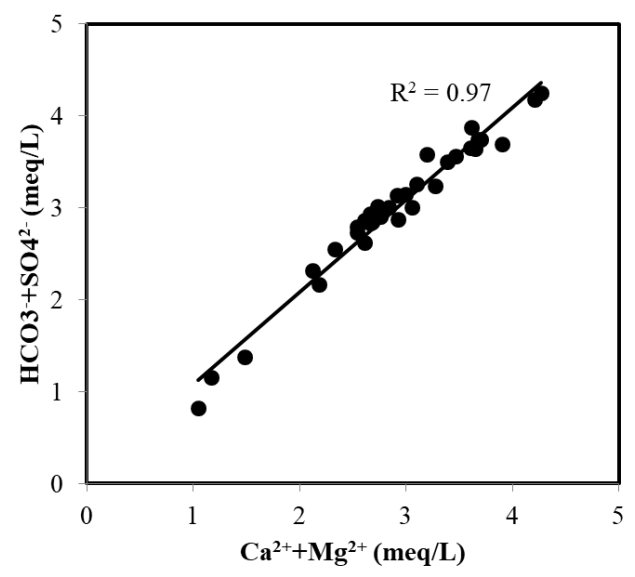

Fig. 2. Relationship between $\left[\mathrm{Ca}^{2+}+\mathrm{Mg}^{2+}\right]$ and $\left[\mathrm{HCO}_{3}{ }^{-}+\mathrm{SO}_{4}{ }^{2-}\right]$ in the Yangtze River.

As indicated by the relationship between $\left[\mathrm{Ca}^{2+}+\mathrm{Mg}^{2+}\right] /\left[\mathrm{HCO}_{3}{ }^{-}\right]$and $\left[\mathrm{SO}_{4}{ }^{2-} / \mathrm{HCO}_{3}{ }^{-}\right]$ shown in Figure 3, data points fall between end-members that expected for erosion of carbonic acid and a combination erosion of carbonic acid and sulfuric acid. Points' falling close to the combined end-member document that sulfuric acid is involved in the chemical weathering of carbonate rocks.

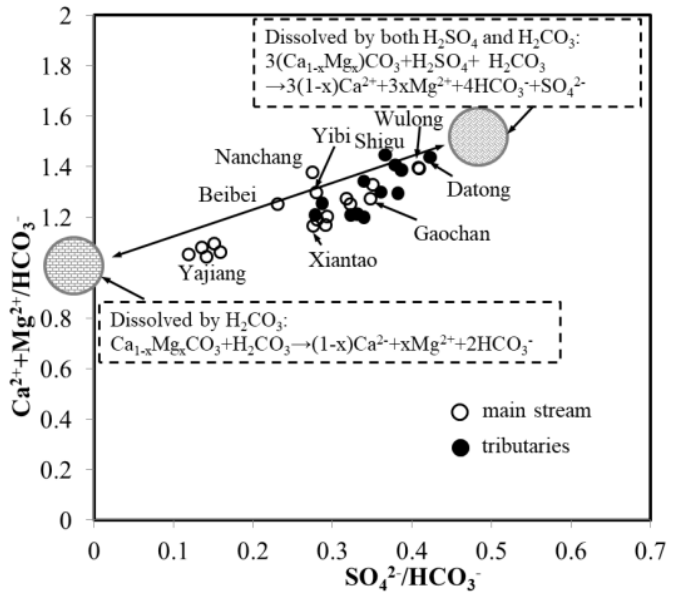

Fig. 3. Relationship between $\left[\mathrm{Ca}^{2+}+\mathrm{Mg}^{2+}\right] /\left[\mathrm{HCO}_{3}{ }^{-}\right]$and $\left[\mathrm{SO}_{4}{ }^{2-} / \mathrm{HCO}_{3}{ }^{-}\right]$for the Yangtze River and its major tributary streams.

\subsection{Sources of $\mathrm{SO}_{4}{ }^{2-}$ in the Yangtze River}

Data for runoff, precipitation, and hydrochemical variables of the Yangtze River were used to quantitatively estimate $\mathrm{SO}_{4}{ }^{2-}$ sources. The annual runoff of the Yangtze River Basin in 2013 was $7969 \times 10^{8} \mathrm{~m}^{3}$. The average concentration of $\mathrm{SO}_{4}{ }^{2-}$ in river was $34.3 \mathrm{mg} / \mathrm{L}$ and the $\mathrm{SO}_{4}{ }^{2-}$ flux was $2734 \times 10^{4} \mathrm{t} / \mathrm{y}$ can be calculated. The annual average precipitation was approximately $940 \mathrm{~mm} / \mathrm{y}[6]$ and the average $\mathrm{SO}_{4}{ }^{2-}$ concentration in the rainwater was 5.76 $\mathrm{mg} / \mathrm{L}[7,8]$. Therefore, the atmospheric deposition of $\mathrm{SO}_{4}{ }^{2-}$ was $974 \times 10^{4} \mathrm{t} / \mathrm{y}$, accounting for 
$36 \%$, i.e. the value of $\mathrm{x}$ in Equation (1), for the total $\mathrm{SO}_{4}{ }^{2-}$ output to the river basin.

In Equation (1), the contribution of $\mathrm{SO}_{4}{ }^{2-}$ from rainwater to the river is $\mathrm{x}$, the contribution from evaporites is $y$, and the contribution from coal is (1-x-y). Then the contribution of $\mathrm{SO}_{4}{ }^{2-}$ from various sources to the river can be calculated as follows:

$$
\delta^{34} S_{\text {river }}=\delta^{34} S_{\text {rain }} \times x+\delta^{34} S_{\text {evaporite }} \times y+\delta^{34} S_{\text {coal }} \times(1-x-y) ;
$$

where, $\delta^{34} S_{\text {river }}, \delta^{34} S_{\text {rain }}, \delta^{34} S_{\text {evaporite, }}$ and $\delta^{34} S_{\text {coal }}$ represent the sulfur isotope ratio of ${ }^{32} \mathrm{~S} /{ }^{34} \mathrm{~S}$ in river, rain, evaporite rocks and coal, respectively. The results indicated that $\mathrm{x}=36 \%$ and $\mathrm{y}$ $=26 \%$. This indicates that $36 \%$ of the $\mathrm{SO}_{4}{ }^{2-}$ in the river was contributed by rainwater, $26 \%$ by dissolution of evaporites, and $38 \%$ by coal.

\subsection{Estimation of rock weathering rate and $\mathrm{CO}_{2}$ consumption}

The Galy model [8] was adopted to estimate the carbons sink proportion from different weathering end-members using ion contents from the hydrochemical analysis. These calculations (Table 1) indicate that the average weathering rate of silicate rock is 6.02 $\mathrm{t} / \mathrm{km}^{2} \mathrm{y}^{-1}$ (column A), the average rate of carbonate rock dissolved by carbonic acid is 50.3 $\mathrm{t} / \mathrm{km}^{2} \mathrm{y}^{-1}$ (column $\mathrm{C}$ ), and the weathering rate increased to $64.5 \mathrm{t} / \mathrm{km}^{2} \mathrm{y}^{-1}$ (column $\mathrm{E}$ ), an increase of $28 \%$, under the combined influence of carbonic and sulfuric acid. The $\mathrm{CO}_{2}$ consumption rate was $22.3 \mathrm{t} / \mathrm{km}^{2} \mathrm{y}^{-1}$ (sum of column B and D) when only the carbonic acid erosion was considered. But the $\mathrm{CO}_{2}$ consumption rate was $19.6 \mathrm{t} / \mathrm{km}^{2} \mathrm{y}^{-1}$ when sulfuric acid erosion was considered (column $\mathrm{B}$ and $\mathrm{F}$ ), which indicates that $12 \%$ of the $\mathrm{CO}_{2}$ consumption in the Yangtze River should be deducted under the role of sulfuric acid.

Table 1. The carbon sink evaluation for the Yangtze River.

\begin{tabular}{|c|c|c|c|c|c|c|c|}
\hline \multirow{3}{*}{ Station } & \multicolumn{2}{|c|}{$\begin{array}{c}\text { Silicates weathered by } \\
\text { carbonic acid }\end{array}$} & \multicolumn{2}{|c|}{$\begin{array}{c}\text { Carbonates weathered by } \\
\text { carbonic acid }\end{array}$} & \multicolumn{2}{|c|}{$\begin{array}{l}\text { Carbonates weathered by } \\
\text { carbonic and sulfuric acid }\end{array}$} & \multirow{2}{*}{$\begin{array}{c}\text { Carbon } \\
\text { sink } \\
\text { flux } \\
\left(10^{4}\right. \\
\left.\mathrm{tCO}_{2} / \mathrm{y}\right)\end{array}$} \\
\hline & $\begin{array}{c}\text { Rock } \\
\text { weathering } \\
\text { rate } \\
\left(\mathrm{t} / \mathrm{km}^{2} \mathrm{y}^{-1}\right)\end{array}$ & $\begin{array}{c}\mathrm{CO}_{2} \\
\text { consumption } \\
\text { rate } \\
\left(\mathrm{t} / \mathrm{km}^{2} \mathrm{y}^{-1}\right)\end{array}$ & $\begin{array}{c}\text { Rock } \\
\text { weathering } \\
\text { rate } \\
\left(\mathrm{t} / \mathrm{km}^{2} \mathrm{y}^{-1}\right)\end{array}$ & $\begin{array}{c}\mathrm{CO}_{2} \\
\text { consumption } \\
\text { rate } \\
\left(\mathrm{t} / \mathrm{km}^{2} \mathrm{y}^{-1}\right)\end{array}$ & $\begin{array}{c}\text { Rock } \\
\text { weathering } \\
\text { rate } \\
\left(\mathrm{t} / \mathrm{km}^{2} \mathrm{y}^{-1}\right)\end{array}$ & $\begin{array}{c}\mathrm{CO}_{2} \\
\text { consumption } \\
\text { rate } \\
\left(\mathrm{t} / \mathrm{km}^{2} \mathrm{y}^{-1}\right)\end{array}$ & \\
\hline & $\mathrm{A}$ & $\mathrm{B}$ & $\mathrm{C}$ & $\mathrm{D}$ & $\mathrm{E}$ & $\mathrm{F}$ & $\mathrm{G}$ \\
\hline Shigu & 1.63 & 0.38 & 24.7 & 10.0 & 31.7 & 8.62 & 210 \\
\hline Yichang & 5.64 & 3.88 & 53.2 & 19.6 & 68.1 & 16.6 & 2049 \\
\hline Datong & 7.37 & 4.10 & 54.6 & 19.7 & 69.7 & 16.5 & 3495 \\
\hline Er'tan & 2.01 & 1.55 & 14.5 & 5.81 & 19.1 & 5.46 & 81 \\
\hline Gaochang & 9.86 & 8.58 & 68.9 & 25.3 & 89.4 & 21.8 & 404 \\
\hline Wulong & 5.80 & 3.72 & 90.3 & 33.9 & 115 & 28.3 & 282 \\
\hline Beibei & 6.61 & 4.30 & 66.4 & 24.7 & 85.0 & 21.2 & 408 \\
\hline Xiantao & 4.80 & 3.84 & 44.2 & 16.8 & 57.1 & 14.8 & 296 \\
\hline Waizhou & 10.5 & 1.88 & 35.7 & 12.5 & 45.1 & 10.5 & 100 \\
\hline Average & 6.02 & 3.58 & 50.3 & 18.7 & 64.5 & 16.0 & $\begin{array}{ll}-- \\
\end{array}$ \\
\hline
\end{tabular}

Datong station, which is the final station along the Yangtze River, represents the total flux of Yangtze River output to the sea. Here, the carbon sink rate is $20.6 \mathrm{tCO}_{2} / \mathrm{km}^{2} \mathrm{y}^{-1}$ (sum of column B and F), of which, $80 \%$ is attributed to the weathering of carbonate rocks. The total output carbon flux from rive to the sea is $3495 \times 10^{4} \mathrm{tCO}_{2} / \mathrm{y}$. For tributaries, the Jialing River and the Min River exhibited the highest $\mathrm{CO}_{2}$ transport and together constituted 22\% of the total carbon sink flux output of the Yangtze River. These were followed by the Han Jiang and $\mathrm{Wu}$ Jiang rivers, each of which constituted $8 \%$ of the total flux output. 


\section{Conclusions}

The relationship between ion equivalent ratios in river water suggests that bedrock dissolution along the Yangtze River is driven by both carbonic acid and sulfuric acid. The utilizing of S-isotopic compositions showed that $36 \%$ of $\mathrm{SO}_{4}{ }^{2-}$ can be attributed to rainwater, $26 \%$ to dissolution of evaporites, and $38 \%$ to derivation from coal. Hydrochemical modeling implies that sulfuric acid accelerates the rate of rock weathering by $28 \%$. For the $\mathrm{CO}_{2}$ consumption, calculation results indicate that $12 \%$ should be deduced when the sulfuric acid erosion is considered.

Results from measurements at the downstream Datong hydrological station indicate that the annual $\mathrm{CO}_{2}$ flux output to the sea is $3495 \times 10^{4} \mathrm{t}$ of $\mathrm{CO}_{2}$. Additionally, the carbon sink rate was $20.6 \mathrm{t} \mathrm{CO}_{2} / \mathrm{km}^{2} \mathrm{y}^{-1}, 80 \%$ of which was attributed to the weathering of carbonate rocks.

\section{References}

1. X Xia, et al. Earth. Sci. Front., 15, 194-202 (2008)

2. JY Li, et al. Chinese. Geogr. Sci., 15, 16-21 (2005)

3. M. Cao, et al. Carsologica sinica, 31, 145-153 (2012)

4. C. Liu, et al. Geochim., 37, 404-414 (2008)

5. X. Wang, et al. Carsologica Sinica., 5, 311-317 (1986)

6. C. Li, et al. Yangtze River. ,44, 11-13 (2013)

7. G. Han, et al. Chem. Geol., 204, 1-21 (2004)

8. A. Galy, et al. Chem. Geol., 159, 31-60 (1999) 